\title{
Media Phraseology and the Dynamics of the Ukrainian Language: the Psycholinguistic and Stylistic Paradoxes
}

\section{Медійна фразеологія та динаміка української мови: психолінгвістичні та стилістичні парадокси}

\author{
Dmytro Syzonov \\ Ph.D. in Philology, \\ Associate Professor
}

\author{
Дмитро Сизонов \\ кандидат філологічних наук, \\ доцент
}

\begin{abstract}
E-mail:_dm_sizonov@ukr.net orcid.org/0000-0003-1162-2182
\end{abstract}

\author{
Kyiv National Taras Shevchenko \\ University, Department of Stylistics \\ and Speech Communication \\ $\triangle 60$, Volodymyrska Str., Kyiv, \\ Ukraine, 01033
}

\author{
Київський наиіональний \\ університет імені Тараса \\ Шевченка, кафедра стилістики \\ та мовної комунікаиії \\ вул. Володимирська, 60, Київ, \\ Україна, 01033
}

Original manuscript received April 12, 2018 Revised manuscript accepted October 15, 2018

\begin{abstract}
The present article involves the study of the dynamic processes of the Ukrainian language in printed and electronic mass media. Specifically, the description of functional paradoxes in the Ukrainian language is further presented in this article, with a particular focus on phraseological units (idioms) that function in mass communication. The sources of new phraseology that percolate into mass consciousness direct it through mass media and all described manipulative strategies show that the journalists like to use phraseological units and their stylistic transformations in media texts from the headline to the conclusion. The author gives scientific interpretation of the term medial phraseological unit (idiom) and its correlation with the term new phraseological unit / phraseological innovation in Ukrainian and European Linguistics. The author gives scientific interpretation of the term medial
\end{abstract}


phraseological unit (idiom) and its correlation with the term new phraseological unit / phraseological innovation in Ukrainian and European Linguistics. The research and analyzes results collected as material for innovative dictionary of new words and phraseological units (2016-2018) showed, that Ukrainian language integrates itself into the world global process, enriches itself with new lexemes thanks to the English Language, has great psycholinguistic influence from the side of active political processes and connected with the innovations development. The results of the data analysis indicate that the ratio of the new idioms to the new vocabulary in the media in Ukrainian points to the pragmatic specificity of the phraseological resources of the Ukrainian language in the twenty-first century. Comparing the corpus media phraseology in 2016 and 2017, it can be concluded that aphoristic quotations of politicians occupy a substantial place among the new phraseologisms $130 \%$ and $32 \%$ respectively), advertising slogans, including political ones (25\% and 23\%), calqued phraseologisms (mainly from the English language) (12\% and $9 \%)$, new clichés and stamps (8\% and 9\%), terminological neologisms (10\% and $12 \%)$, and semantically transformed phraseologisms (15\%).

Key words: idioms innovation, media linguistic analysis, media phraseology, psycholinguistic.

\section{Introduction}

The aim of this article is to define the paradoxical psycholinguistic and stylistic processes in the modern Ukrainian mass communication that influenced the emergence of the new media phraseological idiom. It should be noted that phraseology has been amply researched in a number of previous studies. For example, Sechehaye made a seminal contribution to semantic indivisibility of the phraseological idiom, Potebnya posited the idea of the inner form of the word, Vulfius referred to the idiomaticity of phraseological units, and Hornby composed a dictionary of phraseological idioms with the etymology and modern semantics of sustainable units. Phraseological innovations in different areas of social communication, psycholinguistic, and communicative linguistics are considered by Styshov (2003), Bacevych (2004), Taranenko (2015), and Pashynska (2011).

It should be noted that in the English linguistic tradition the term idiom is widely used as a stable expression and a precedent statement, as well as formulaic speech as a boilerplate phrase that is associated with different types of communication. Therefore, the use of this stylistic 
resource in the different functional areas is very specific according to the purpose of communication and usage pattern.

The definition of new phraseology (neophraseology, phraseological innovation) as a concept depends to an extent on the content of neologism as a linguistic term, interpretation of which has traditionally been a subject of debate. Although definitions differ in some respects, neologism is generally considered a new word, a new meaning of the existing naming unit, or an author's personal innovation that is occasional in nature. The novelty of such naming units is in the consciousness of the mass communicant. With the common interpretation of neologism in mind, a phraseological neologism is ipso facto a fixed linguistic formation that appears and gains purchase in the language in line with the needs of the age. Arguably, mass media are the main driver and a mirror of new phraseology's inception (Shevchenko \& Syzonov, 2017: 13). Importantly, phraseological innovation has not been covered by any contemporary dictionary or other lexicographic work so far. Presumably, phraseological innovation encompasses not just newlycoined fixed expressions and those born from the existing phraseology but also those expressions that are actualised under the new social conditions or borrowed from other languages.

\section{Data and Methods}

The present research is based on the theory of functional stylistics and methods of complex interpretation of the text. The diagnosis of texts involves searching for new words and phraseologies in the Ukrainian language on the basis of the method of media monitoring (Dobrosklonskaya, 2008: 30). We have chosen a wide range of Ukrainian media editions of different types, electronic and printed. Using the continuous sampling method on different thematic groups we recorded new words and phraseologisms, which were not previously recorded in lexicographic editions in Ukraine (thus, we used the lexicographic method which involves fixing and further stacking of linguistic units in a card file to the dictionary). In order for a linguistic unit to be considered a new and frequent for the Ukrainian consciousness, it should be recorded in 10 different sources in at least 10 contexts. For stylistic marking of units (e.g., positive, negative and neutral), Wolf's scale (2002) is used. In the study, stylistic parameters of new linguistic units are defined by semantic and derivative methods. The method of data 
counting has objectified the thesis that $1 / 4$ of the new linguistic units are phraseologisms. The obtained results are important for proving dynamic processes in the Ukrainian language that are manifested in replenishing the active vocabulary of Ukrainian at the expense of primarily the English language.

\section{Results}

Preparing for publication the innovative dictionary «New words and phraseology in the Ukrainian media» (Shevchenko \& Syzonov, 2017), we tried to collect the most complete registry of neolexis and neophraseology in the mass communication in Ukraine. The convincing point is the availability of the wide range of media sources (the total of 44), allowing for an objective screening of new linguistic units (Figure 1).

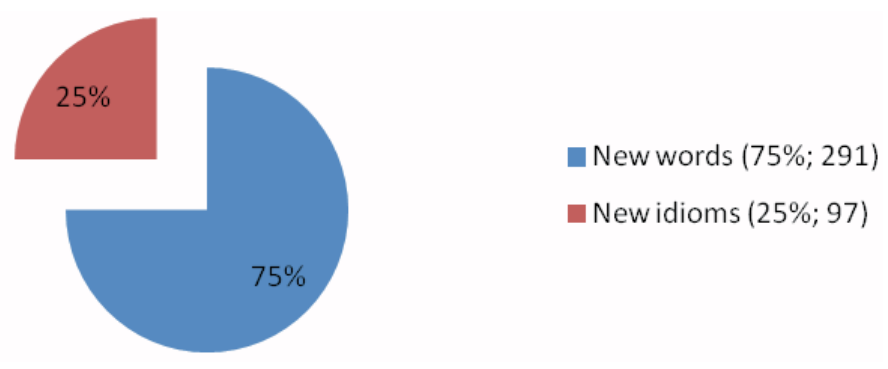

Figure 1. New words \& idioms*

* «New words and phraseology in the Ukrainian media / L. Shevchenko \& D. Syzonov» (issue 1; year 2016)

The main criterion is the «novelty», which is defined in the innovation dictionary quite clearly: absence of new words / idioms in dictionaries, frequent use in the media texts (at least ten times), verbal designation of a new phenomenon or event, replication of the neo-unit in the broad context outside the mass-media style.

Out of 388 new collected units that are represented in the dictionary, 97 are new idioms, of which almost a third (32\%) are the quotations of politicians, $23 \%$ - advertising slogans, $9 \%$ - calque phraseological idioms borrowed mainly from the English language, $9 \%$ - new clichés and stamps of the official-business style, $12 \%-$ terminological neologisms and 15\% are semantically transformed idioms. 
It is also noteworthy that in 2017 the trend for an emergence and operation of new idioms in mass communication remains to be unchanged (see comparative table). New phraseological sources in the media remain to be political processes, advertising, the English language (remember the concept of the language imperialism developed by the American scientist R. Phillipson), as well as the media itself, which actively replicate the traditional phraseology in the transformed version, when their meaning and semantics vary depending on the actual realities (Figure 2).
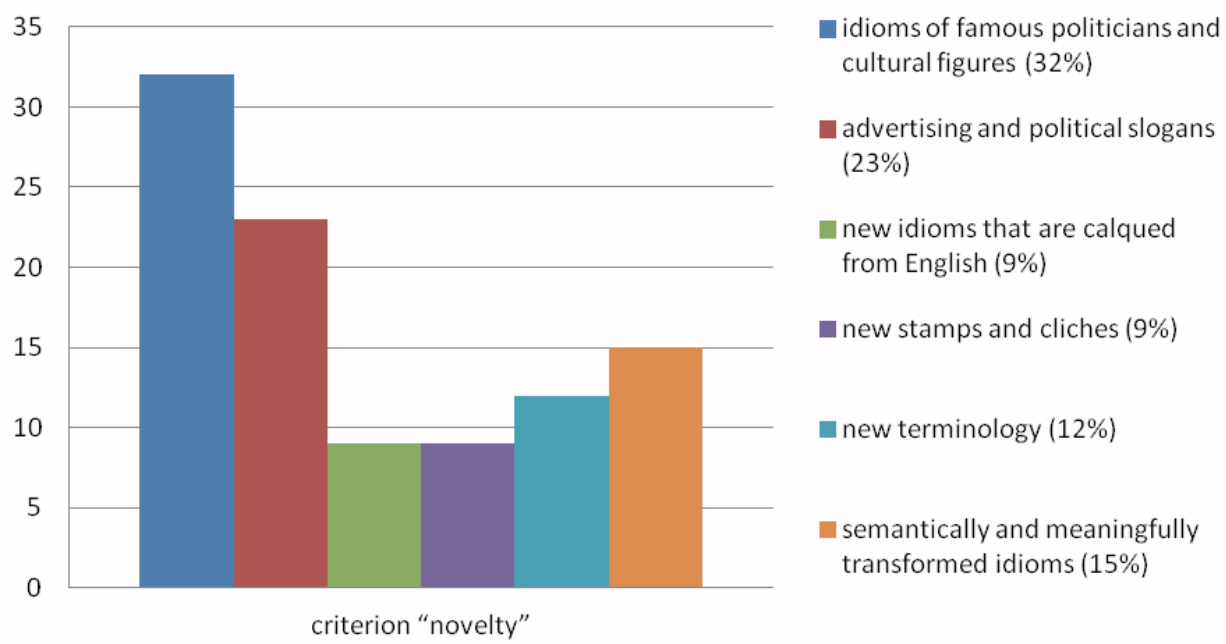

Figure 2. Types of new idioms in the Ukrainian media*

* «New words and phraseology in the Ukrainian media / L. Shevchenko \& D. Syzonov» (issue 1; year 2016)

In fact, we can argue about the appearance of new phraseological units in the ratio of $1 / 4$ to new words encountered in the media (Table 1). The information space, in this case, is a powerful source for a replenishment of the vocabulary of the modern Ukrainian language with new idioms that are actively promoted by the mass audience and are activated in the future without the reference to time of the occurrence.

Therefore, we want to accumulate the scientific achievements concerning the understanding of phraseological innovation and propose a criterion that would take into account the peculiarities of the media development discourse of the $21^{\text {st }}$-century. 
Медійна фразеологія та динаміка украӥнськоӥ мови...

Table 1. Ratio of new idioms in 2016* and 2017**

\begin{tabular}{lcc}
\hline \multicolumn{1}{c}{ TYPES } & $\mathbf{2 0 1 6 *}$ & $\mathbf{2 0 1 7} * *$ \\
\hline $\begin{array}{l}\text { Idioms characterized by the idiomatic character that also are } \\
\text { the quotations of famous politicians, cultural figures } \\
\text { and other famous individuals }\end{array}$ & $32 \%$ & $30 \%$ \\
$\begin{array}{l}\text { Advertising and political slogans } \\
\text { New idioms that are calqued from other languages, } \\
\text { mainly from English }\end{array}$ & $23 \%$ & $25 \%$ \\
New stamps and cliches & $9 \%$ & $12 \%$ \\
New terminology & $12 \%$ & $8 \%$ \\
Semantically and meaningfully transformed idioms & $15 \%$ & $15 \%$ \\
\hline
\end{tabular}

* «New words and phraseology in the Ukrainian media / L. Shevchenko \& D. Syzonov» (issue 1; year 2016);

** «New words and phraseology in the Ukrainian media / L. Shevchenko \& D. Syzonov» (issue 2; year 2017);

According to our observations, the following can be considered as the new media idiom:

(a) idiom that emerged in the mass media field and has not been recorded by idiom's dictionaries;

(b) idioms characterized by the idiomatic character that also are the quotations of famous politicians, cultural figures and other famous individuals;

(c) advertising and political slogans that are reflected in mass consciousness and are being replicated to the broad masses;

(d) new idioms that are calqued from other languages, mainly from English and which are reflected in the Ukrainian media space;

(e) new stamps and clichés of the official-business style;

(f) new terminology of the phrase that bears the semantic stability and is actively being used in the media language;

(g) transformation of terminological combinations by means of the phenomenon of the semantic determinologization in the media;

(h) different types of metaphorical periphrase with the constant media replication;

(i) semantically and meaningfully transformed idioms that are actualized in the language of the media; 
(j) allusional and reinterpreted idioms related to the category of intertextualism in the media

(k) youth slang words that have a constant reproducibility in the mass media;

(1) occasional idioms that are actively replicated in the mass media.

The corpus was based on the headlines of posts taken from Facebook and Twitter and was aimed at determining the emotions which arise in respondents reading them (Syzonov, 2017).

\section{Discussion}

The analysis of idioms in various communicative situations was the object of investigation in world science, which is represented in the form of system dictionaries (see lexicographical works Dictionary of American Idioms and Phrasal Verbs, 2005; Cambridge International Dictionary of Idioms, 1998 etc.). Researchers have recently drawn attention to the mechanisms of influence of language units on individual / mass consciousness (Botta \& Chemlab, 2016; McGinnis 2002), although this problem in linguistics has always been of interest to scholars, particularly in a multidisciplinary context.

We have chosen this promising exploratory path, analyzing an idiom / a phraseologism in a psycholinguistic context in media. It is also possible to highlight new ideas which are proposed in the context of the given article: the impact of an idiom / a phraseologism on a recipient in different types of Ukrainian media in the context of Ukraine's dynamic integration processes into the European Union.

Medialinguistics involves approaches to social communication, like psychology (and syncretic sciences - psycholinguistics, suggestive linguistics, and neurolinguistics), when it comes to the analysis of mass media phraseology. As to the psycholinguistic approach, it should be clarified that such phenomena as «manipulation of media text», «influence on collective consciousness», «emotional evaluation of linguistic units in media», «information tactics», etc. are all a product of psychological methods and strategies and should be considered as controversial in the context of Ukrainian and other languages.

Considering phraseology as a certain expressive linguistic universal, German media linguists (Perrin, 2006) argue that phraseological locutions are used in mass media mostly with manipulative intent. Metaphorical, connotative, and evaluative, such units make the language 
of mass media more vivid and expressive and tend to gain new shades of meaning. Besides, they may be used in the direct or modified contexts (Dobrosklonskaya, 2008: 114).

Shevchenko (2004) emphasizes the importance of phraseology in Slavic languages in the European context since the dynamics of linguistic processes depend largely on extralinguistic factors like the economic, cultural, and political development. Taranenko (2015) draws attention to the evolutionary processes in the modern age, pointing out that derivative process in lexicon and phraseology has been reflected the most widely in language transformations.

The global practice - Polish medialinguistics and psycholinguistics specifically - has been focused on the applied aspect of the problem over the recent decade (especially when it comes to influencing collective consciousness in the context of global information warfare). The analysis of new phraseology in media texts is the object of not only linguistic but also psychological study, especially when it comes to compiling recommendations as to proper text production, the manipulative intent of a statement, logical presentation of the material with respect to time condition, etc. (Zgółkowie, 1999; Gajda, 2015). New phraseological locutions have a special purpose - they are a verbal reflection of the real situation in the society, which shows the dynamism of literary language.

We, too, gravitate toward the modern European scientific trend, focusing on the detailed functional analysis of linguistic units in the media landscape (as well as their effect on a mass recipient).

The semantic nature of phraseology is known to be debatable and sometimes even contradictory (Gajda, 2015: 12). Especially in the language of mass media, phraseological locutions may be used not only in their traditional meaning but also in a non-standard one to enhance expressiveness. New phraseological locutions that arose in the mass media language - in political communication, for instance - have a call to action aspect, which may affect the behaviour of people in some situations. E.g., in advertising and PR, phraseology may constitute a basis for so-called «advertising hypnosis», and in political discourse be used in speeches and slogans.

The role of phraseology in various structural parts of media texts is a subject of debate in the modern media linguistics. Since they have the strongest semantic aspect in headlines and leads, the functional 
side of phraseological locutions (traditional, transformed, and new) is a premise for creating a new breed of dictionaries - the description of such innovative dictionaries has been attempted in Ukrainian media lexicography (Shevchenko, 2014).

It is worth noting about the background knowledge of recipients in this context, meaning that idiom can be a specific marker of the social life providing that there is the relevance of the event to an author and a reader. Media is a powerful tool in the fixation and further popularization of the phraseology - both traditional and modern. Lets remember the views of Vezhbickaja (2001) who perceived phraseology as a verbal sign, which is also a part of the national culture. Those media phraseological idioms that remain in the mass consciousness regardless of they time frame in which they occurred are considered to be universal for media. Recalling the phraseological units that were trending under certain political circumstances in Ukraine, but remained in the mass consciousness of our time, having passed the semantic test of the time.

We emphasize that in the definition of the media phraseology we follow the European scientific tradition, and therefore we consider it is necessary to submit our own interpretation of this concept, to the definition of which we include both extra-and intralingual features: a media idiom

(1) is the language universum of the media style,

(2) a certain mental massively-verbal code that is characterized by an authentic sense, semantic integrity, emotionality and expressiveness,

(3) is the Slavonic language universum (Syzonov, 2017) that provides the media text with the wide stylistic potential to influence a recipient and to manipulate his mind.

In our view, the problem of identifying the idiomatic character of new phraseological units in different types of communication remains a controversial issue. This question is partially solved on the example of English, Russian, Lithuanian, French, and Spanish languages (see articles by Howarth, 1998; Knappe, 2005; Baranovskaja, 2016; Pinnavaia, 2000 etc.). The analysis of stylistic functions and psycholinguistic tactics of new phraseologisms in Ukrainian media is conducted for the first time.

We have found phraseological innovation to have the following features: 
(1) fixed form; (2) high functional and stylistic variability; (3) evaluativity of a certain communicative situation; (4) a disposition to linguistic economy manifested in speakers' predilection for the most efficient means of communication, including phraseology; (5) substantial enhancement of terminological collocations and industry words the neophrasemes are based on; (6) not being included in earlier dictionaries of neologisms; (7) psycholinguistic communication basis - the ability to influence individual/mass consciousness with words.

The formation of new phraseology is affected by professional, technical, and overall cultural awareness of language speakers and the increasing importance of media (press, radio, cinema, TV, and Internet) in the current public communication.

Nowadays, the phraseology that represents certain social phenomena becomes increasingly frequent in the language of media. To understand it, recipients must have certain background knowledge. Some examples are палити шини (to fight for something), майданити (to revolt), старший брат (about Russia), ворог народу (about the one who opposes government), etc.

We believe the terminological fields the most popular and accessible to mass audience - healthcare, economy, tourism, law - have been instrumental in coining of new phraseology: чума 20 століття, хвороба року, смертельнии вірус - from healthcare, презумпиія невинуватості, конституиійне право, законна / незаконна операції - from law, тіньовий / сірий ринок, валютний курс, фінансова піраміда - from economy, гарячий тур, «все включено», туристичний шопінг - from tourism.

Perhaps the most frequent source of enrichment for the contemporary language's phraseology dictionary is imparting a new tone and meaning to the existing phraseological unit. To us, the main functional paradox in this context is the transformation of phraseology as a manipulative factor in mass media: "Скільки Ахметова не годуй...» (transformation of the Ukrainian well-known saying (idiom) «Скільки вовка не годуй...»), «Даєш демократичну Європу» (an adaptation of M. Kvylyovyi's slogan «Даєш психологічну Європу» / «Psychological Europe Now!»), «Не треба кидати долари на вітер» (stylistic transformation «Кидати гроші на вітер»), etc. (the examples provided are rough translations of the phraseology found on «Gazeta.ua», a Ukrainian Internet-media). 
The phraseology originating in the 1990s jargon is still relevant and used nowadays: бізнесова «крима», «шліфуй базар», «усіх

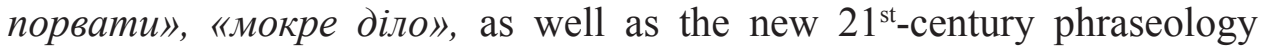
spawned by the recent events: «нові донецькі» (similar to «новых русских»), «виловити тітушек», «золотий батон» (as a symbol of wealth and embezzlement), etc. Such phraseology is also used in media with manipulative intent to describe the modern phenomena with references to the past.

Among the sources for coining of new phraseology are also terminological collocations (through semantic determinologisation). Taranenko wrote about this derivation-level phenomenon: «when a terminological collocation is regularly used in its figurative meaning, we are talking about the creation of a new phraseological unit, the one that fits the needs of the age» (Taranenko, 2015: 85). Shifting from their usual scope of use into the literary language, terminological collocations lose their meaning as a term, gaining a related figurative meaning. Thus, the terminological collocation becomes a so-called semantic guide for a new phraseological unit: отримати прописку (in Parliament, in Kremlin): Екс-регіонали уже отримали прописку $i$ додому повертатися не збираються; перейти у наступ (entered sports, politics and economics from military): Свропа перейшла у наступ $і$ санкиії розширюються; взяти тайм-аут (from sports): $У$ переговорах взято тайм-аут (the examples provided are rough translations of fragments taken from «День» and «Газета по-українськи»), etc.

Without a doubt, the conversational style is among the main sources of the modern phraseology too. It was the spoken word that gave us proverbs, sayings, riddles, and catchphrases. The new phraseology of mass media also originates in neologisms, youth slang, and even vernacular. The new phraseology may be as follows: 3 nорогy (straight away), зацінити (evaluate), на приколі (about weird behaviour), без базару (in earnest), ловити кайф (to like something very much), піднятися на новий левел (to reach a new social level), etc. The facts of life (political, economic, social, in general) enrich the language with new phraseology too (collocations gain additional meaning): голосувати двома руками (to vote wrongfully), з високої трибуни (solemnly), ... як до Президента (about someone busy and often unavailable), без розуму unthinking, stupid). Colloquialisms used mostly outside of literary context may also become a source of new 
phraseology: брехати правду (to lie), тюхати туфту (to go negative on someone); прикриватися бабами (i.e. fearing something/someone, being unwilling to accept responsibility), забити стрілку (to set the time and place to meet), etc.

We stress that the majority of new phraseologisms are created and actively replicated in media. We record such phraseological innovations in the series of our dictionaries «New words and phraseology in the Ukrainian media» (Shevchenko \& Syzonov, 2017) in order to reveal dynamic processes of the language which occur under the influence of extralinguistic and, particularly, psychological factors of communication.

Therefore, we deem it expedient to study and analyse comprehensively the new phraseology, especially that used in the media, which will help illustrate the dynamics of linguistic processes in the living language of the $21^{\text {st }}$ century. Like no other, psycholinguistic methods help monitor the new phenomena in the language, including phraseology, which is used to manipulate mass consciousness of the Ukrainians.

\section{Conclusions}

The analysis of modern scholarly body of work on media linguistics with respect to psycholinguistic features of media communication thus shows that application of phraseology in mass media offers great opportunities. Linguistics know diverse interpretations of media phraseology, which is indicative of a great functional, stylistic, and psycholinguistic potential of these linguistic units in mass communication. This can be attributed to writers' efforts to mainstream the pro-active attitude or to emotionally influence the reader with their texts. In the theory of mass communication, media phraseology is not just a constituent linguistic unit. It has a wider meaning - that of a certain concept, an expressive universal, which imparts additional emotional intensity to a mass media text. We believe that coining of new phraseology is the largest functional paradox of media communication and it is aimed at fulfilling the main functions of the media - those of communication and manipulation.

\section{References}

Bacevych, F. (2004). Osnovy komunikatyvnoi lingvistyky [Introduction to communicative linguistics]. Kyiv, Ukraine : Akademija [in Ukrainian]. 
Media Phraseology and the Dynamics of the Ukrainian Language...

Baranovskaya, I. (2015). Naujas žodis kalbotyroje: lietuviu kalbos frazeologija [A new word in linguistics: the phraseology of the Lithuanian language]. Vilnius, Lithuania : Naujoji šviesa [in Lithuanian].

Botta, L., \& Chemlab, E. (2016). Shared and distinct mechanisms in deriving linguistic enrichment. Journal of Memory and Language, 91. 117-140. https:// doi.org/10.1016/j.jml.2016.04.004

Dobrosklonskaya, T (2008). Medialingvistika: sistemnyj podhod $k$ izucheniju jazyka SMI [Medialinguistics: A systematic approach to learning the language of the media]. Moscow, Russia : Flinta; Nauka [in Russian].

Gajda, S. (2015). Aktualnye zadachi stilistiki [Actual tasks of stylistics]. Aktualnye problemy stilistiki - Actual problems of stylistics, 1, 5-17. Moscow, Russia : University of Moscow [in Russian].

Howarth, P. (1998). Phraseology and secondlanguage proficiency. Applied Linguistics, 19, 24-44 [in English].

Knappe, G. (2005). Idioms and Fixed Expressions in English Language Study before 1800. Frankfurt am Main, Germany : Peter Lang [in English].

Mc Ginnis, M. (2002). On the Systematic Aspect of Idioms. Linguistic Inquiry, 33, Issue 4. 665-672. https://doi.org/10.1162/ling.2002.33.4.665 [in English].

Pashynska, L. (2011). Frazeologichni neologizmy v suchasnomu ukrainskomu masmedijnomu dyskursi [Phraseological neologisms in modern Ukrainian massmedia discourse]. Kyiv, Ukraine : KNLU [in Ukrainian].

Perrin, D. (2006). Medienlinguistik. Konstanz, Germany : Utb. [in German].

Phillipson, R. (1992). Linguistic Imperialism. Oxford, UK : Oxford University Press [in English].

Pinnavaia, L. (2000). English Idiomatic expressions: a historical pragmatic analysis. Di Martino G. \& Lima M. (Eds.), English Diachronic Pragmatics (Proceedings of the Conference held at the Istituto Universitario Suor Orsola Benincasa, Naples, 13-15 May 1999). Naples, Italy : CUEN, 339-352 [in English].

Shevchenko, L. \& Syzonov, D. (2017) Novi slova ta frazeologizmy v ukrainskyh masmedia [New words and phraseologisms / idioms in the Ukrainian mass media]: dictionary. Kyiv, Ukraine: Kyivskyj universytet [in Ukrainian].

Shevchenko, L. (2014) Medijna leksykografija $v$ lingvistychnij perspektyvi [Medialexicography in the linguistic perspective]. Actual issues of Ukrainian linguistics: theory and practice, 28, 7-16. Kyiv, Ukraine : Kyivskyj universytet [in Ukrainian].

Shevchenko, L. (ed.) (2004). Literaturna mova u prostori naciona'noi kultury [Literary language in the space of national culture]. Kyiv, Ukraine : Kyivskyj universytet [in Ukrainian].

Shevchenko, L., Syzonov, D., \& Dergach, D. (2014). Medialingvistyka: slovnyk terminiv $i$ ponjat [Medialinguistics: glossary of terms and concepts]. Kyiv, Ukraine : Kyivskyj universytet [in Ukrainian].

Styshov, O. (2003). Ukrainska leksyka kincja XX stolittja (na materiali movy zasobiv masovoi informacii) [Ukrainian lexis of the end of the $20^{\text {th }}$ century (in the media)]. Kyiv, Ukraine : KNLU [in Ukrainian].

Syzonov, D. (2017). Psycholinguistic bases of media literacy: considering the issue of media texts interpretation. Science and education, 7, 82-88. https://doi. org/10.24195/2414-4665-2017-7-13 [in Ukrainian].

Taranenko, O. (2015). Aktualizovani modeli v systemi slovotvorennja suchasnoi ukrainskoi movy (kinec XX-XXI st.) [Actualized models in the system of word 
Медійна фразеологія та динаміка украӥнськоӥ мови...

formation of the modern Ukrainian language]. Kyiv, Ukraine : Vydavnychyj dim Dmytra Burago [in Ukrainian].

Van Dijk, T. (1997). What is Political Discourse Analysis? Belgian Journal of Linguistics, 11(1), 11-52. https://doi.org/10.1075/bjl.11.03dij [in English].

Vezhbickaja, A. (2001). Ponimanie kultur cherez posredstvo kljuchevyh slov [Understanding cultures through key words]. Moscow, Russia : Jazyki slavjanskoj kultury [in Russian].

Wolf, E. (2002). Funktsionalnaia semantika otsenki [Functional Semantics of Evaluation]. Moscow, Russia : Editorial URSS [in Russian].

Zgółkowie, T. (1999). Poprawność językowa a skuteczność komunikacyjna [The popularity of communication and communications]. Wrocław, Poland : DDS [in Polish].

\section{АНОТАЦІЯ}

Дослідження передбачає вивчення динамічних процесів української мови на основі мас-медіа - друкованих та електронних. В контексті медіадосліджень передбачається опис стилістичних та психолінгвістичних парадоксів в українських мові, зокрема вивчаються фразеологічні одиниці (ідіоми), які активно функціонують в масовій комунікації. Аналізуються джерела нової фрразеології, що проникають у масову свідомість, керують нею через засоби масової інформації, описані маніпулятивні стратегії, до яких вдаються журналісти у зв'язку з активним використанням фразеологізмів та їх стилістичних трансформацій у медіатекстах - від заголовка до висновку. Автором подається наукова інтерпретація поняття медійний фразеологізм (ідіома) $і$ його кореляція з поняттям новий фрразеологізм / фразеологічна інновація в українській та європейській лінгвістиці. Результати дослідження і аналізу зібраного матеріалу до інноваційного словника нових слів та фразеологізмів (2016-2018) показали, що українська мова інтегрується у світовий глобальний процес, поповнюється новими лексемами завдяки англійській мові, має великий психолінгвістичний вплив з боку активних сучасних політичних процесів, у зв'язку з розвитком інновацій. Автор з використанням статистичного методу обчислює співвідношення нових ідіом до нового лексичного складу в засобах масової інформації, що дозволяє довести прагматичну специфріку фразеологічного ресурсу української мови на поч. XXI столітті. Порівнюючи зібраний матеріал у 2016 ma 2017 роках, ми дійшли висновку, що афористичні цитати політиків посідають найбільше місце серед нових фразеологізмів (30\% і 32\% відповідно), далі - рекламні слогани, в т.ч. політичні (25\% / 23\%), кальковані фразеологізми (переважно з англійської мови) (12\% / 9\%), нові кліше та итампи (8\% / 9\%), термінологічні неологізми (10\% / 12\%), семантично трансрормовані фразеологізми (по 15\%). 
Media Phraseology and the Dynamics of the Ukrainian Language...

Ключові слова: ідіоматичні інновації, медіалінгвістичний аналіз, медіафразеологія, психолінгвістика.

\section{Сизонов Дмитрий. Медиафразеология и динамика украинского языка: психолингвистические и стилистические парадоксы}

\section{АННОТАЦИЯ}

Исследование предусматривает изучение динамических процессов украинского языка на основе масс-медиа - печатных и электронных. В рамках медиаисследований предполагается описание стилистических и психолингвистических парадоксов в украинском языке, в частности изучаются фразеологические единицы (идиомы), которые активно функционируют в массовой коммуникации. Анализируются источники новой фразеологии, которые проникая в массовое сознание, управляют им (сознанием) через СМИ, описаны манипулятивные стратегии, $k$ которым прибегают журналисты в связи с активным использованием фразеологизмов и их стилистических трансформаций в медиатекстах от заголовка до заключения. Автором подается научная интерпретация понятия медийный фразеологизм (идиома) $и$ его корреляция $c$ понятием новый фразеологизм / фразеологическая инновация в украинской и европейской лингвистике. Результаты исследования на основе собранного материала к инновационному словарю новых слов и фрразеологизмов (2016-2018) показали, что украинский язык интегрируется в мировой глобальный процесс, пополняется новыми лексемами в основном из английского языка, имеет большое психолингвистическое влияние со стороны активных современных политических процессов, в связи с развитием технических инноваций. Автор с использованием статистического метода вычисляет соотношение новых идиом к новому лексическому составу в средствах массовой информации, что позволяет доказать прагматическую специфику фразеологического ресурса украинского языка в нач. ХХІ века. Сравнивая собранный материал в 2016 и 2017 годах, мы пришли к выводу, что афористические цитаты политиков занимают наибольшее место среди новых фрразеологизмов (30\% и 32\% соответственно), далее - рекламные слоганы, в т.4. политические (25\% / 23\%), фразеологизмы-кальки (преимущественно из английского языка) (12\% / 9\%), новые клише и штампы (8\% / 9\%), терминологические неологизмы (10\% / 12\%), семантически трансрормированы фрразеологизмы (по 15\%).

Ключевые слова: идиоматические инновации, медиалингвистический анализ, медиафразеология, психолингвистика. 